This item was submitted to Loughborough's Research Repository by the author.

Items in Figshare are protected by copyright, with all rights reserved, unless otherwise indicated.

\title{
The future of youth justice
}

\section{PLEASE CITE THE PUBLISHED VERSION}

https://doi.org/10.1177/1473225418791416

\section{PUBLISHER}

(C) The Authors. Published by SAGE Publications

\section{VERSION}

AM (Accepted Manuscript)

\section{PUBLISHER STATEMENT}

This work is made available according to the conditions of the Creative Commons Attribution-NonCommercialNoDerivatives 4.0 International (CC BY-NC-ND 4.0) licence. Full details of this licence are available at: https://creativecommons.org/licenses/by-nc-nd/4.0/

\section{LICENCE}

CC BY-NC-ND 4.0

\section{REPOSITORY RECORD}

Case, Stephen, and Kevin Haines. 2019. "The Future of Youth Justice". figshare. https://hdl.handle.net/2134/33425. 


\section{The Future of Youth Justice}

Youth justice in England and Wales is, yet again, at a point of departure and change; some might say a point of crisis. The Youth Justice System of England and Wales is still expected to be effective, efficient and economical, but with less money, fewer staff with fewer resources, less time and larger caseloads - all at a time of intense political and socio-economic uncertainty. Change may be a constant across the history of youth justice (Case 2018), but as the pressure builds for system reform, this change becomes more urgent, sporadic and diverse. Indeed, change is already happening change to the structures, policies, strategies and practices that constitute youth justice across England and Wales.

So what is the future of youth justice? Predicting this future raises a series of pertinent issues: What could youth justice look like in terms of its principles, systems, structures, strategies, policies and practices? What should it look like? Is there a future for dedicated youth justice services? Should there be? These are critical questions and we need some kind of answer - sooner rather than later. Predicting the future is, however, fraught with difficulty. No-one can truly know what will happen, which is ironic when examining a Youth Justice System (YJS) shaped by actuarial risk prediction for the past 20 years. Unexpected events can throw off long-term developing strategies and trajectories overnight (Lorenz 1963). The opposite outcome to that predicted is as likely to occur as the predicted outcome. Youth justice is not immune to such chaos and uncertainty, exemplified by recent political and socioeconomic upheavals stemming from Brexit and the US presidential election. You could argue that the only predictable aspect of youth justice is its unpredictability. So, how can we begin to address questions about its future?

The central aim of this paper is to map out the contours of youth justice policy and practice in England and Wales, to sketch out the terrain on which youth justice is currently changing and to understand how its future is being constructed. In doing so, we intend to identify and explore the opportunities, tensions and blockages that characterise contemporary youth justice policy and practice in England and Wales. As such, there is no clear (or indeed, necessary) central narrative, save for the relative absence of policy to address the current normlessness in youth justice and to shape and cohere increasing local variations in the formation and delivery of youth justice. This will be a complex analysis, with no easy answers or simple ways forward. However, the need to sketch out, understand and change youth justice is a challenge that faces all responsible key stakeholders. The discussion that follows covers the main issues for the development and delivery of youth justice policy and practice in England and Wales at the current time, evaluating these (where appropriate) against a backdrop of international trends. There will inevitably be certain issues omitted that others think deserve due consideration. If so, we apologise in advance and invite others to add to our analysis. There is no particular priority or significance to the order in which we present these issues. All are relevant to understanding contemporary youth justice policy and practice in England and Wales. All overlap and interact in complex ways. Ultimately, the dynamic, complex and multi-faceted outcomes of the relationships and inter-sections between these issues will be the product of many decisions made by many people.

\section{Youth justice at the point of change: Two decades of divergence}


Contemporary youth justice is already changing. Some of these changes have been set out elsewhere (e.g. Hopkins-Burke 2016; Arthur 2016; Haines and Case 2015; Dunkel 2014) and we commend readers to these more detailed accounts. Although youth justice has been in a perennial state of change since 'youth offending' was socially constructed in the 19th century and 'youth justice' was constructed to respond to it (Case 2018), the pace of this change has accelerated rapidly since the late 1990s. When 'New Labour' came to power in the United Kingdom in 1997, they committed to responding to children who offend through the lens of 'new youth justice' (Goldson 2000), underpinned by strategies of responsibilisation and prevention that were animated by a model of risk-focused intervention known as the 'Risk Factor Prevention Paradigm' (Farrington 2007). As a result, youth justice policy cohered around targeting the criminogenic role of 'risk factors' and pursuing the prevention of risk and reoffending. Risk-led policy formations increasingly shaped explanations of youth offending and the purportedly evidenced-based 'effective practice' and 'what works' responses to it in England and Wales (Case and Haines 2009), as they did in many areas of North America and Australasia, at least until the second decade of the $21^{\text {st }}$ century (Case 2018). For example, risk assessment inventories (e.g. Asset, Onset) and risk-led intervention programmes (e.g. the Scaled Approach, Youth Inclusion Programmes/Support Panels) underpinned the 'Key Elements of Effective Practice' and 'Key Performance Indicators' by which the performance of Youth Offending Teams (YOTs) and their practitioners is monitored and managed by the Youth Justice Board (Stephenson, Giller and Brown 2011). Over the first decade of the new youth justice (1998-2007), the zenith of the Risk Factor Prevention Paradigm (RFPP) in England and Wales, there were mixed results across the three main key performance indicators for YOTs and the YJS: a general decrease in first-time entrants into the YJS (but annual rises from 2003-2006), little change in annual reoffending rates (the proportion of the annual offending cohort who reoffend) and significant increases in custody levels (Solomon and Garside 2008). There was also a notable increase in the imposition of punitive offence- and offender-focused interventions over this period (Deloitte 2015; Muncie 2014).

The following decade (2008-2017) evidenced more promising outcomes: annual decreases in first-time entrants (FTEs), falling numbers of children reoffending (although rates remained stubbornly consistent, largely due to a smaller cohort possessing more complex needs than previously - Taylor 2016) and diminishing use of custody for children, consolidated by decreases in arrest rates and the use of disposals - out-of-court cautions and court convictions (MoJ 2017). Notably, the second half of this decade also witnessed a tentative move away from the RFPP as the all-encompassing animator of youth justice policy and practice. The Scaled Approach to risk-based assessment and intervention was abolished in the face of sustained critique from academics, policy makers and practitioners (YJB 2014). It was replaced with AssetPlus, a less risk-focused framework that builds in more scope for practitioners to assess foundations for change, desistance mechanisms, strengths, the voices/perspectives of children and to utilise their professional discretion (YJB 2013). However, in the continued absence of a clear alternative policy direction with which to inform and shape post-risk practice, many of YOTs have fallen back on (riskbased) offence- and offender-focused approaches and responses (e.g. to assessment) over more child-focused or rights-facing prevention or diversion activity (Hampson 2017; Deloitte 2015). The contemporary policy vacuum also appears to have encouraged policy-makers to seek sanctuary in the well-worn and familiar risk 
paradigms, drawing once again on the RFPP as the gold standard for effective practice recommendations relating to preventing offending (YJB 2017) and reducing reoffending (MoJ 2016a).

\section{A state of normlessness}

It is now widely recognised by politicians, policy-makers, practitioners and academics that youth justice policy and practices vested too much faith in the RFPP (YJB 2014), a perspective echoed across other major risk-led youth justice contexts internationally such as the USA (cf. Goddard and Myers 2016) and Australasia (cf. Johns, Williams and Haines 2017). Critics argued that the implementation of the RFPP in youth justice systems internationally was harmful to children due to its labelling and interventionist tendencies (Muncie 2014; Paylor 2011) and neglected and even breached requirements of international children's rights instruments such as the United Nations Convention on the Rights of the Child (Goldson and Muncie 2015). It was also claimed that the RFPP evidence-base was weak, misrepresented and even nonexistent (Case and Haines 2009). In particular, critics argued that the statistical indicators of 'success' (e.g. falls in FTEs and custody rates) were not the product of risk-based policy and practice. Instead, these ostensible systemic improvements were attributed to a number of influences, including the (2008) abolition of the police's 'Offences Brought to Justice' target, enhanced use of diversion at the out-of-court stage and cultural and practice changes at the local level leading to less tolerance to punitive youth justice and more use of local mediation and practitioner discretion to adapt centralised policy prescriptions (Phoenix 2016; Bateman 2017). Across key stakeholder groups, from Government Ministers and officials, to the Youth Justice Board (YJB) who monitor and manage the YJS, to those engaged in youth justice practice at the local level, there has been a discernable disavowing of risk-based youth justice policy and practice in recent years (Smith 2013), despite recent episodes of relapse evident in effective practice guidance (cf. YJB 2017). The loss of faith in the RFPP has left a conceptual and theoretical vacuum in youth justice policy and practice. As we write this paper in early 2018, there exists a state of normlessness in youth justice policy and practice in England and Wales; an absence of coherent policy from Government and the YJB and a lack of consensus amongst critical academics/researchers and across youth justice practice as to the 'right' way to go to build on the effective practice of local areas and to address temporary challenges such as service retraction and working with cohorts demonstrating multiple complex needs. Lack of consensus and the presence of ambiguity around appropriate youth justice policy and practice have encouraged complexity and hybridity in how youth justice has been conceived and delivered. In this sense, the youth justice context in England and Wales is reflective of the international context - complex, hybrid and constantly changing, with no clear consensus as to a single model or approach to pursue (cf. Goldson 2014; Dunkel 2014; McAra 2010). The potential for local variations in the shaping and delivery of youth justice (e.g. through mediation of national policy prescriptions or local innovation in the absence of policy) is manifest - both as an opportunity and attention for current and future youth justice.

\section{Youth justice by geography: Local variations}

The current normlessness of youth justice policy and practice exacerbates the potential for 'justice by geography' - the differential treatment of children who offend based solely on where they live, due to the relative absence of coherent national policy, which has encouraged local variations in the conceptualisation and 
implementation of youth justice, along with the mediation of centralised policy and guidelines by local youth justice cultures, organisations (e.g. police, courts, YOTs) and practitioners. The term 'justice by geography' was coined by Norman Tutt and Henri Giller (1987) to denote the main finding of their research that children experienced differential treatment by the YJS in England and Wales depending on locality and most notably that this led to differential outcomes for children. Those familiar with youth justice practice in England and Wales will know that justice by geography has been a persistent and enduring feature - marked by what can be quite radically different practices and outcomes for children between and within neighbouring authorities. This, in turn, raises the question of whether analysts should talk in terms of 'England and Wales' when discussing youth justice policy and particularly practice. Even at times when the level of central Government direction over policy has been very high, practice at the local level has varied widely (see Armitage, Kelly and Phoenix 2016; Taylor 2016; Drake, Fergusson and Briggs 2014; Kelly 2012; Haines and Case 2012; Sutherland 2009).

A broader example of local variation is offered by the striking youth justice policy differences between England and Wales. Many social policy areas related to youth justice (e.g. education, social services, health) are devolved to the Welsh Government. Social policy making for children in Wales coheres around principles of social democracy, collective responsibility and unconditional access to universal 'entitlements' (maximum outcomes from services) articulated in the 'Extending Entitlement' youth inclusion strategy (NAPU 2000). Conversely, the English social policy agenda for children has emphasised neo-liberalism, individual responsibility and conditional access to rights (minimum standards of service), articulated in the 'Every Child Matters' (DfE 2004) strategy.

In the youth justice sphere in England, there has been an hiatus in central Government policy since the Conservatives assumed power in 2010 (initially in coalition with the Liberals), largely due to the emergence of more pressing priorities in political and economic terms. Over this same period, Wales has adopted a distinctive youth justice policy direction reflective of its social policy principles and underpinned conceptually by the 'children first, offenders second' model of positive youth justice (Welsh Government and YJB 2014; see also Haines and Case 2015). Tensions and contradictions between (devolved) social policy and (centralised) youth justice policy in Wales have been addressed through the 'Children and Young People First' youth justice strategy (Welsh Government and YJB 2014), which eschews punitive, adultcentric youth justice in favour of pro-social, child-friendly responses. This approach enjoys advocacy from Welsh Government and YJB Cymru (the Welsh division of the YJB) - indicative of the importance placed on central leadership of a distinct, 'dragonised' policy and practice identity for Wales (Haines 2010), whilst rendering the term 'England and Wales' in reference to youth justice policy increasingly problematic. Policy divergence has not, of course, precluded practice differences between local authorities in Wales. Indeed, the distinctive Welsh policy may have even increased the level of practice variations between local areas as they have responded to local circumstances. Crucially, however, local practice variations in Wales in response to local circumstances have developed within a coherent 'children first' policy framework. Local divergence outwith this framework has been more readily visible and tackled with pro-active assistance from YJB Cymru (cf. Case 2014). Conversely, the absence of a coherent, explicit youth justice policy framework 
in England has allowed the emergence of unchecked divergences in policy and practice at the local level.

The extent of local variations in practice between and within England and Wales renders youth justice a challenging area of study. As soon as one reaches a conclusion or makes a statement about youth justice practice, it can be readily challenged or disproved by glancing across a county border. However, are local variations necessarily a bad thing? From a central Government perspective, local variation could be viewed negatively, as a failure of local agencies to effectively implement Government policy and as a weakening of State control. On the other hand, the relative absence of policy due to the withdrawal of the State, combined with the emergent localisation agenda, could be seen as empowering local areas and practitioner discretion. In particular, the ability of local agencies to exercise discretion in the construction and implementation of policy could be seen as an opportunity to put right what is wrong with centralised Government policy - and is therefore a good thing. Furthermore, no two localities are exactly the same. Every local area experiences conditions and events that are unique and, it is argued, those responsible for policy implementation in every local area must respond to their specific challenges. Consequently, some variation in practice and outcomes is both inevitable and desirable. The opportunities and tensions highlighted by the complex localnational relationship are echoed internationally (e.g. within Australian juvenile justice - see Johns et al 2017; Cunneen, Goldson and Russell 2016), as multiple competing pressures, both external and internal, push and pull youth justice developments (e.g. principles, policiers, practices) in different directions. However, the manifestations of these tensions are rooted in the local context.

The question then becomes: what level of local variation in practice and outcomes is justified? There is no obvious answer to this question. It is difficult, if not impossible, to answer in a readily quantifiable manner. We would argue that there should be at least a degree of coherence to policy and practice at central and local levels (see, Haines and Case 2015; Haines and Drakeford 1998). Once again, the precise degree of coherence is difficult, if not impossible, to establish, but there should (must) be some degree of coherence in approach or philosophy to guide practice. This is necessary for each and every child processed through the YJS and for evaluation(s) of the quality of practice and outcomes to be realised against established criteria. What we can be certain of in the present time is that the level of local variation in practice between and within areas is unacceptable. This is partly because each local area has, for a number of years now, followed its own path in implementing youth justice services and the paths taken have diverged widely, from the punitive to the riskfocused to the child-friendly (Case 2018; Smith 2017; Goldson 2014; Hazel 2008) and from focusing solely on identified offenders to more preventative strategies (Case and Haines 2015). Local divergence has also (at least partly) stemmed from the hiatus in youth justice policy that has permitted the emergence of divergent paths. There is, therefore, a difference between local divergences within a common coherent framework and divergences that share little or nothing in common. These differences can be very important and significant - especially if you are a child.

\section{The future of change}

The extent of variation and divergence in local youth justice practice in England and Wales has been made possible because Government has been looking the other way. 
As late as 2015, Michael Gove, as Minister of Justice, commissioned Charlie Taylor to conduct a review of the YJS and to make recommendations for system reform on the basis that youth justice remains expensive (e.g. due to the excessive use of custody) and ineffective (e.g. due to consistently high reoffending rates), despite longer-term evidence of statistical success in relation to falling levels of FTEs and indeed custody. Taylor's recommendations reflected much of the 'children first' approach advanced in Wales and animated in areas of England (e.g. Surrey, Greater Manchester), infused with educational measures reflective of his background as a headteacher of a school for children with behavioural problems. Two main structural recommendations were forwarded: diversionary Children's Panels following sentencing by the Youth Court and educational Secure Schools to replace custodial institutions (Taylor 2016). Strategically, Taylor recommended more integrated service provision across the youth justice, education, health and welfare sectors, combined with greater scope for local devolution and discretion in the governance, funding, monitoring and delivery of youth justice practice (i.e. actively encouraging local mediation and variations in practice).

Notwithstanding the energy, innovation and good intentions of the review recommendations have been stalled in implementation by successive justice ministers (three and counting) since Michael Gove’s Brexit-inspired sacking in July 2016. The Government response to Taylor's recommendations was inconsistent and lacking in enthusiasm, largely the product of the political and economic paralysis caused by Brexit. The Government asserted that it 'will be implementing his [Taylor's] key recommendations by putting education at the heart of youth custody and improving the provision of healthcare to tackle the factors that increase the risk of offending' (MoJ 2016b: 3). Consequently, there was rhetorical support for enhancing the focus on education (and to a lesser extent health) across the YJS, although very little was mentioned regarding mental health or welfare. There was also tentative support for local devolution and discretion through a vague commitment to exploring how local areas could be given greater flexibility to improve youth justice services, but no more definitive detail was provided. There was further tentative, rhetorical support for more focus on education in the Secure Estate (e.g. through the creation of Secure Schools) and a degree of local devolution. However, many of Taylor's recommendations were not responded to fully, contradicted or entirely ignored by the Government. For example, the principle of responding to children who offend as 'children first' was completely overlooked, as were proposals for Children's Panels, more local discretion around diversion schemes and most controversially the potential abolition of the YJB. Indeed, in direct contradiction to the review recommendations, the main focus of the Government response was to reinforce the existing system priority of prevention through early intervention and risk-focused strategies (cf. the 'new youth justice'). According to the Government, the most effective way to reduce crime is 'to intervene early and to prevent children and young people from committing offences in the first place' (MoJ 2016b: 4) and so best practice in the area of prevention should be disseminated across the system. Ironically, in March 2017, Taylor was installed as the new Chair of the YJS, adding even more uncertainty and ambivalence to the future direction and shape of youth justice in England and Wales. Despite the recent announcement of Taylor's YJB appointment, youth justice in England is very much on the Government back burner and it seems set to stay there. The policy vacuum endures, possibly even more so in the context of the unconnected reform proposals 
contained in Taylor's review and the ambiguity and partiality of the Government's official response to them.

Perhaps paradoxically, the time when there was the greatest coherence to youth justice practice in England was during the mid- late-1980s, also a time when the Conservatives were in power and when the gaze of Government was elsewhere (under Margaret Thatcher's programme of radical social and economic reform). To fill this void, a practitioner-led youth justice movement emerged, which came to be known as 'new orthodoxy thinking' (see Haines and Drakeford 1998). New orthodoxy thinking cohered youth justice practice around the dual goals of minimising custody and maximising diversion from prosecution for children - it was coherent, dominant and successful on its own terms (see Allen 1991). Of course, both minimising custody and maximising diversion are explicit goals of the contemporary YJS. There is one major difference, however, between the 1980s and 2010s - economic austerity. Whilst in the 1980s, Government spending remained relatively high, Government economic policy in the 2010s has shifted into austerity measures, with significant consequences for youth justice.

\section{Economic austerity and the gaze of management}

The full complexities of economic austerity are beyond the scope of this paper, but in brief, they have involved significant reductions in (centrally-prescribed) local authority budgets; necessitating major cuts in local authority services. Inevitably, some of these cuts have been targeted at youth justice services. From a YOT perspective, whilst in some areas these financial cuts have been deep, they have not, generally speaking, been the major consequence of austerity. The single, most significant change wrought by economic austerity has been that YOTs are now increasingly subject to the gaze and hands-on decision making of senior local authority managers (typically from social services departments).

For most of the history of providing services to children who offend (certainly since the Beveridge report led to the creation of local authority social services departments in 1971), youth justice services have been provided by specialists in a changing professional landscape of: Intermediate Treatment Teams, Juvenile Justice Teams, Youth Justice Teams and most recently YOTs. Throughout this nearly 50-year period, these specialist teams have operated largely outwith the gaze and outwith the direct management of senior local authority managers. To be sure, there have been links and lines of accountability, but these mechanisms have been weak (Morgan 2009; Souhami 2007). Local authority managers have typically been drawn from other specialist services (e.g. child care, adult services) and very few (unless drawn from a youth justice background) have been 'experts' or 'specialists' in youth justice. For example, an Audit Commission review in 2004 discovered that fewer than a quarter of the Chief Officers' Groups that YOTs reported to were chaired by heads of Children's Services, with the majority chaired by the Chief Executive of the local authority (Audit Commission 2004). Many senior managers in local authorities (rightly or wrongly) have been content to allow YOT managers and YOTs to get on with the job - with little or no interference. There has been an historical lack of engagement between YOTs and local authorities, often due to the YOT's partnership nature rendering it semi-autonomous from individual partners locally, a dynamic reinforced by the input from individual partners being a relatively small part of the YOT's overall operation (Audit Commission 2004; Morgan 2009). In addition, YOTs 
were not created to be an arm of the local authority (Home Office 1998), but rather a multi-agency partnership sitting between children's services and criminal justice to be monitored and managed by an 'independent' YJB that often bypassed the local authority when pursuing its management function. Thus, YOTs have functioned unlike any other public service for children and the lines of accountability regarding their management and performance have been inevitably blurred (Bateman 2017; Morgan 2009; Souhami 2007).

In the changing landscape of local authorities wrought by economic austerity, changing relationships between central and local government and the increased potential for local devolution of youth justice responsibilities, however, YOTs have been increasingly subject to the direct management and decision-making of senior managers who may not understand the professional context and knowledge base of YOTs. This is a serious situation, with far reaching consequences. Lacking the requisite professional knowledge to understand the specialist nature of youth justice, senior local authority managers are increasingly likely to make uninformed decisions about what services should be provided, who should provide these services and what structures of service delivery are best suited to this purpose.

Conversely, it should be recognised that economic austerity has precipitated a relative withdrawal of the State (e.g. Government, YJB) from the centralised management of local youth justice practice. A financially-induced retreat from the managerialism and (policy) prescription of the new youth justice (e.g. intensive performance management of YOTs) has provided space for the development of more innovative and pragmatic policy and practice that is more sensitive to local contexts, including local bureaucratic hierarchies and occupational cultures (see Taylor 2016; Souhami 2015; MoJ 2012). This climate of localised governance, innovation and 'devolution' of youth justice responsibilities in the face of austerity has provided an opportunity to re-examine costly and counter-intuitive institutional practices such as custody and net-widening (Yates 2012; see also YJB 2015) and the broader criminalisation of social policy that has occurred under the new youth justice of the Crime and Disorder Act 1998 (Souhami 2015; Jamieson 2012). It is entirely possible, therefore, that increasingly localised youth justice practice in the form of mediation and innovation, is largely responsible for increasingly successful youth justice outcomes in terms of reduced FTEs and custody rates. This local mediation and innovation has emerged largely without or certainly with less centralised support in financial and practical terms, particularly in England (YJB 2015; Haines and Case 2015; Kelly and Armitage 2015). However, the relative withdrawal of the State, couched in terms of local devolution, yet largely animated by a reduction in centralised target setting (other than targets for system retraction - Phoenix 2016) has also prompted a radical retraction in levels of (youth justice) service provision, especially for the poorest children in England and Wales (Bateman 2015; Yates 2012). Consequently, those children who do enter the YJS, who are disproportionately likely to present with additional complex needs and problems, now receive a diminished service from those who entered the system a decade before them. So what is the future for youth justice?

\section{Changing structures for service delivery}

Like youth justice more broadly, the specific structures for the delivery of youth justice services across England and Wales are already changing and have already been changed. Yet the organisational structure of youth justice services is a topic 
rarely visited (but see Audit Commission 1996; Souhami 2007, 2015; Morgan 2009; Taylor 2016). Few stakeholders in youth justice, whether academics, central and local officials, or indeed, organisational specialists outwith the profession, have shown much interest in organisational structures and their relationship to the type and range of services provided to children who offend. Nevertheless, this relationship is strong and it must be understood in the current context of rapid change, austerity and the proliferation of localised practice models (see Kelly and Armitage 2015).

Anyone familiar with the history of juvenile/youth justice could draw the inevitable, self-fulfilling links between organisational structures and the types and range of services provided. If you build large residential schools for 'delinquents' (e.g. the Reformatories and Industrial Schools of the mid-19 ${ }^{\text {th }}$ century - see Hopkins-Burke 2016), then these structures will fill with children (some of whom will be hardly delinquent at all). If you build Borstals and Detention Centres, then they will fill with children, who are subsequently subjected to harsh punitive regimes (Arthur 2016) many of whom will have committed minor offences. If you create Intermediate Treatment teams with a remit to work with children in need, some of whom may have committed offences, they will provide a wide array of community-based services to ever expanding numbers of children (see 'Out of Care' - Thorpe et al 1980). If you establish youth justice teams, they will focus on the relationship between the behaviour of children and the criminal justice response (cf. new orthodoxy thinking). If you create multi-agency YOTs, they will develop a range of services from prevention, through diversion, to various forms of direct intervention (Souhami 2007). Whilst the relationship between organisational structure and the type and range of services provided is not wholly determinative, it is very real. To adapt Parkinson's Law, the population of children who offend expands to fill the structures created for it.

Across England and Wales, the traditional YOT structure is already breaking down. Indeed, Taylor (2016) implicitly recommended abolishing the requirement for such structures in his review through repealing the Crime and Disorder Act 1998 (which required local authorities to establish a YOT). Some local authority areas have implemented subtle internal changes and altered the type and range of services provided (sometimes following decisions of senior managers, sometimes led from within the YOT itself). Indeed, it can be argued that the current changing climate of YOT structures and services is reflective of a longer-term trend precipitated by the blurred lines of accountability for their design and management. Commenting on the evolution of YOTs since the Crime and Disorder Act 1998, Smith (2013: 96-97) argues that 'the turbulent nature of organisational arrangements for local government and children's services led to a considerable degree of fluidity and a wide range of differing models for co-ordination and delivery of youth offending services'. Whilst there is currently no map of local authority 'youth justice' services across England and Wales, it is possible to discern a range of emerging organisational structures and the type and range of services being provided. In attempting to outline these changes below, it is important to remember that 'youth justice' itself is in a state of flux and almost as soon as one commits something to paper, it has changed yet again. It is also important to acknowledge the dynamic nature and influence of local variation within the same organisational structures. Nevertheless, it behooves us to set out the broad parameters of recent organisational change: 


\section{YOTs}

Not all local authority areas have changed their basic organisational structure of the post-Crime and Disorder Act YOT. Most of these areas have, however, been subject to budgetary restrictions that have had an impact on the range of services provided, the quality and depth of these services, and the children benefitting from them. Nevertheless, in these areas, there has been a serious attempt made to retain the basic YOT organisational structure and the type and range of services provided. A recent 'stocktake' of YOTs discovered that 15\% operated as standalone units (Deloitte 2015);

\section{YOTs minus}

In some local authority areas, the appearance of the 'traditional', standalone YOT structure has been maintained, but the type and range of services provided has retrenched. In these areas YOTs no longer typically engage in the provision of preventative services, nor do they actively engage in measures designed to divert children from the formal YJS. In the main, a 'YOT minus' area focuses its attention on identified 'young offenders' who are already embroiled in the YJS. These areas may even retain a risk-based approach and typically follow offence- and offenderfocused interventions. Diversion and prevention (and the children who benefit from them) are increasingly likely to be neglected in these localities (Deloitte 2015; see also YJB 2015);

\section{Merged management}

In a number of local authority areas, YOTs have been integrated or merged with other services (typically Children's Services - Deloitte 2015) under a unified manager, in line with Taylor's recommendations for more service integration (Taylor 2016). In these areas, YOTs retain their essential structure and the type and range of services provided. What makes this arrangement unique, however, is that the YOT is now managed by someone who typically does not (necessarily) come from a youth justice background and this manager, in addition to managing the YOT, also manages another service that operates from a separate team such as youth or family services (YJB 2015). The consequences of these integrated arrangements are diverse, but they can encourage mainstream services to 'step aside' and abrogate responsibility to YOTs (Taylor 2016) and they can lead to a diminution and dilution in the type, range and quality of youth justice services, along with an erosion of specialisation (YJB 2015);

\section{Children First areas}

What distinguishes a 'Children First' area is that the organisational structure created for the delivery of services is a secondary matter. What comes first are the needs of children and the type and range of services that are required to promote the best possible outcomes for children (following Haines and Case 2015). Typically, in these areas, the full range of services are provided to children: from pure, universal prevention (see Taylor 2016) to diversion (see Smith 2017; Kelly and Armitage 2015) to individualised and targeted (albeit sometimes risk-focused) prevention (see Kelly 2012) to child-focused interventions that aver offence- and offender-focused work in favour of promoting positive behaviours and outcomes for children (see Byrne and Brooks 2015). The organisational structures created to deliver the Children First approach have varied. In some local areas, services have been provided by YOTs (Jones and Axon, in Case 2018). Other areas have merged YOTs with, for example, 
the Youth Service to create a new unified structure (e.g. Surrey Youth Support Service - Byrne and Case 2016). What distinguishes these areas, however, is that they put children first.

It should be clear from the foregoing discussion that there is a quintessential relationship between the structures created for the delivery of services and the type, range and purpose of those services. At present, in England and Wales, there is a lack of consensus on all of these matters, a lack of clarity and an absence of direction and leadership (notwithstanding the Children First policy direction in Wales). This is a serious issue. The current divergent and incoherent pattern of youth justice service delivery across England and Wales is verging on chaos and it requires urgent attention. What is at risk here, in addition to the jobs of youth justice professionals, is the future of our children.

\section{The future of youth justice: What will work?}

At the beginning of this paper we asked: Is there a future for dedicated/specialised youth justice services in England and Wales and should there be? Our answer to both of these questions is an equivocal: yes. Responses to children who offend must be evidence-based. Whilst space precludes anything approaching a comprehensive review of the current state of evidence of 'what works' in relation to philosophies, strategies and practices of youth justice, it is incumbent upon us to provide an overview of our assessment of this evidence. In our view, what most definitely does not work is youth justice practice framed by punishment, system contact, treatment or offender-focused interventions. There is no compelling evidence that punishment (retribution) is effective- if effectiveness is defined in terms of reducing reoffending. Indeed, there is evidence that punitive responses can actively encourage reoffending by children for a variety of reasons, including: lack of rehabilitation to address the root causes of offending, toxic mix with other 'offenders' (including adults), engendering feelings of illegitimate treatment and the restriction of future opportunities through labelling and criminalisation processes (Lotti 2016; Kelly 2012). Similarly, there is evidence that contact with the formal YJS increases the likelihood of reoffending and future involvement with the YJS (McAra and McVie 2015; Richards 2014) due to criminogenic labelling processes (McCord 1978), compounded by the exacerbation of their existing psychosocial problems (Steinberg et al 2004), unmet needs (Haydon 2014) and socio-structural disadvantage (Yates 2012) once labelled as a 'young offender' (Smith 2017). The formal YJS is, therefore, potentially iatrogenic. Furthermore, the efficacy of treatment is difficult to evidence in a context beset by lack of consensus as to what actually causes of offending by children (Thorpe et al 1980; Haines and Drakeford 1998; McGrayne 2011). More specifically, welfare-based approaches to treating identified needs are ineffective as they promote adult-centric and overly-discretionary service delivery models (Phoenix and Kelly 2013) rooted in pseudo-psychological notions of problematic childhoods (Haines and Case 2015; Morgan 2002) rather than focusing on children as active, agentic constructors of their own lives (France at al 2012). Finally, there is evidence that offence- and offender-focused interventions, including the plethora of Americanised, pseudo-psychological 'what works' programmes (Morgan 2002; Phoenix 2016), are ineffective in reducing recidivism and may actually promote recidivism (e.g. Haydon 2014; Haines and Case 2012), a situation compounded by a paucity of academic evidence to support the view that targeting individualised, 
psychosocial risk factors reduces the potential for future offending (Goddard and Myers 2016; Case and Haines 2009).

So what might work to reduce offending/reoffending and this address the policy lacuna in contemporary youth justice, both in England and Wales and internationally? We see significant potential in enhancing at least three key areas of practice in this regard: expert analysis, specialised youth justice workers and children first approaches.

Expert analysis - Evidence regarding effective youth justice responses is complex (and sometimes contested). It is often beyond the comprehension of generic workers. Furthermore, the evidence is wide-ranging and developing, and this takes time to master and maintain. It requires a specialist to understand the evidence and to implement it in practice situations, hence the utility of integrating more expert analyses into policy and practice development. For example, partnerships between YOTs and practice-facing academics can generate meaningful, practical evidence with which to evolve youth justice on the ground (YJB 2016), as can using academics to train YOT staff to become 'pracademics' (Posner 2009) - active researchers and knowledge producers in youth justice (Drake et al 2014). Indeed, the YJB increasingly recognises the potential for 'wider collaboration between practitioners and academics' through its Youth Justice Research Map (YJ B 2018), which is intended to 'enhance the impact of research on practice' and to more widely disseminate the available youth justice evidence base. A notable example of 'effective practice' in this area is the formalised knowledge transfer partnership between Manchester Metropolitan University and the group of YOTs in the Greater Manchester area, a partnership known as 'Greater Manchester Youth Justice University Partnership' (Jones and Axon, in Case 2018). Collaboration with academics at the policy development level is also being prioritised, for example, through the positioning of a recent (academic stakeholder) addition to the YJB membership in an explicit link/conduit role to support policy-academic collaboration.

Specialist youth (justice) workers - The lives of some children who become embroiled in the YJS have been and are so disadvantaged and harmful that it requires specialists who understand the linkages between (particularly negative) life experiences and offending, and who are capable of working with children in this situation (YJB 2009; Burnett and Appleton 2004). These specialist practitioners may be explicitly youth justice-focused (e.g. the youth justice staff within the integrated Youth Support Service in Surrey), but equally they may be specialists in (possibly neglected) areas of the child's life that have demonstrable relationships with offending, such as speech and language therapists or staff from the Child and Adolescent Mental Health Service. According to the recently revised position statement of the Association of YOT Managers, 'youth justice work should be undertaken by dedicated and specialist youth justice workers led by senior managers with substantial youth justice experience positioned at a senior level within local structures' (AYM 2018). As long as youth crime is defined and proscribed in law, as long as some kind of YJS exists, there will be the need for specialist practitioners who understand how this system operates and who can contribute their specialist knowledge to multi-agency and integrated responses to children who offend (Burnett and Appleton 2004; Eadie and Canton 2002). Non-specialists make too many mistakes. 
Children First approaches - There is an emerging evidence base that adopting a Children First approach to conceptualising offending by children and to delivering youth justice has the greatest potential for reducing first-time entry into the YJS, reducing future offending (including its frequency and severity) and for promoting a range of positive outcomes for children such as access to rights and entitlements, family cohesion, educational attainment, citizenship and gaining employment (see Haines and Case 2015; Byrne and Brooks 2015). The principles of Children First have been successfully applied to the implementation of practice models founded on child-friendly intervention (Goldson and Muncie 2006; see also Taylor 2016), diversion from the formal YJS (Byrne and Case 2016; Haines et al 2013), practice with children underpinned by engagement (Prior and Mason 2010), participation (YJB 2016) and evidence-based partnership (Jones and Axon, in Case 2018; Case 2014). Children First shows most promise amongst contemporary models of youth justice practice, exemplified by its central position in the National Policing Strategy for the Policing of Children and Young People (treating young people as children first in all encounters with the police - National Police Chiefs' Council 2015), sentencing guidelines for magistrates/judges (child-focused sentencing that avoids criminalisation and acknowledges that children are not fully developed - Sentencing Council 2017) and recommendations for improving YOT practice (designing children first practice, acknowledging that children are not fully developed/culpable - Taylor 2016).

There will, no doubt, be readers who agree with our assessment set out above and some that disagree (in whole or in part), such is the nature of academic and professional debate. What remains to be addressed, however, is why and how the above advances the argument that specialist youth justice workers are necessary. Our equivocation in answering the questions at the beginning of this section is, therefore, based partly on the resolution of questions concerning what type of youth justice system we have in England and Wales (together or separately)...

\section{Conclusion: What is the future of youth justice?}

Returning to the challenges established at the outset of this paper, it is clear that there is a future for youth justice in England and Wales, but also that no-one truly knows what that future will be. There is a need for expert analysis to inform specialised youth justice services and for professional workers to deliver these services, but noone truly knows what any of these will look like. The current state of youth justice in England and Wales (as a whole) is one of incoherence and divergence approaching chaos. This chaos is manifest in the divergent organisational structures that are emerging for the delivery of youth justice services and the consequences these structures have for the type and range of services provided. It is manifest in the divergent professional ethos that is shaping the delivery of youth justice services in different local authority areas. It is manifest in the vastly different outcomes children obtain depending on where they live.

If youth justice, as a concept and a method of practice, is to survive, then leadership is required. This leadership must set an over-arching, coherent and cohering policy context that is simultaneously bold and flexible enough to facilitate local areas responding to their local circumstances in evidence-based and integrated ways that support children towards pro-social maturation. 


\section{Bibliography}

Allen, R. (1991) Out of Jail. The Reduction in the Use of Penal Custody for Male Juveniles 1981-88. The Howard Journal of Criminal Justice, 30/1: 30-52.

Armitage, V., Kelly, L. and Phoenix, J. (2016) Janus-Faced Youth Justice Work and the Transformation of Accountability. Howard Journal of Crime and Justice, 55/4: 478-495.

Arthur, R. (2016) The Moral Foundations of Youth Justice. Abingdon: Routledge.

Association of YOT Managers (2018) 'Where we stand on' position statements. www.aym.org.uk (Accessed January 15 ${ }^{\text {th }}, 2018$ ).

Audit Commission (2004) Youth Justice 2004. London: Audit Commission.

Audit Commission (1996) Misspent Youth. London: Audit Commission.

Bateman, T. (2017) The state of youth justice 2017: an overview of trends and developments. London: NAYJ.

Bateman, T (2015) The state of youth justice 2015: an overview of trends and developments. London: NAYJ.

Burnett, R. and Appleton, K. (2004) Joined-Up Services to Tackle Youth Crime. A Case-Study in England. British Journal of Criminology, 44 (1): 34-54.

Byrne, B. and Brooks, K. (2015) Post-YOT Youth Justice. Howard League What is Justice? Working Papers. London: Howard League.

Byrne, B. and Case, S.P. (2016) Towards a Positive Youth Justice. Safer Communities, 15 (2): 69-81.

Case, S.P. (in press) Contemporary Youth Justice. Abingdon: Routledge.

Case, S.P. (2014) Strategic complexities and opportunities in Welsh youth justice: Exploring YJB Cymru. Safer Communities, 13(3): 109-119.

Case, S.P. and Haines, K. R. (2015) Children First, Offenders Second Positive Promotion: Reframing the Prevention Debate. Youth Justice Journal, 15 (3): 226-239.

Case, S.P. and Haines, K.R. (2009) Understanding youth offending: Risk factor research policy and practice. Cullompton: Willan.

Cunneen, C., Goldson, B. and Russell, S. (2016) Juvenile Justice, Young People and Human Rights in Australia. Current Issues in Criminal Justice, Vol 28, No 2, pp. 173 188.

Deloitte (2015) Youth Offending Team Stocktake. London: Deloitte.

Department for Education and Skills (2004) Every Child Matters. London: DfES. 
Drake, D, H.; Fergusson, R. and Briggs, D.B. Hearing new voices: re-viewing youth justice policy through practitioners' relationships with young people. Youth Justice, 14/1: 22-39.

Dunkel, F. (2014) Juvenile Justice Systems in Europe - Reform developments between justice, welfare and 'new punitiveness'. Criminological Studies, 2014/1.

Eadie, T. and Canton, R. (2002) Practising in a Context of Ambivalence: The Challenge for Youth Justice Workers. Youth Justice, 2/1: 14-26.

Farrington, D. P. (2007) 'Childhood risk factors and risk-focused prevention', in M. Maguire, R. Morgan and R. Reiner (eds) The Oxford Handbook of Criminology, $4^{\text {th }}$ Ed. Oxford: Oxford University Press.

France, A., Bottrell, D. and Armstrong, D. (2012) A Political Ecology of Youth and Crime. London: Palgrave.

Gatti, U., Tremblay, R.E. and Vitaro, F. (2009) Iatrogenic effect of juvenile justice. Journal of Child Psychology and Psychiatry, 50/8: 991-998.

Goddard, T. and Myers, R. (2016) Against Evidence-based Oppression: Marginalized Youth and the Politics of Risk-based Assessment and Intervention. Theoretical Criminology, 21/2: 151-167.

Goldson, B. (2000) The New Youth Justice. Lyme Regis: Russell House.

Goldson, B. C. (2014). 'Youth Justice in a Changing Europe: Crisis Conditions and Alternative Visions'. Perspectives on Youth, Vol. 1: 39-52.

Goldson, B. and Muncie, J. (2015) Youth Crime and Justice. London: Sage.

Goldson, B. and Muncie, J. (2006) Rethinking youth justice: Comparative analysis, international human rights and research evidence. Youth Justice, 6(2): 91-106.

Haines, K.R. and Case, S.P. (2015) Positive Youth Justice: Children First, Offenders Second. Bristol: Policy Press.

Haines, K.R. and Case, S.P. (2012) Is the Scaled Approach a Failed Approach? Youth Justice, 12 (3): 212-228.

Haines, K.R. (2010) The Dragonisation of Youth Justice. In: W. Taylor, R. Hester and R. Earle (eds) Youth Justice Handbook. Cullompton: Willan.

Haines, K.R. and Drakeford, M. (1998) Young People and Youth Justice. London: Palgrave.

Hampson, K. (2017) Desistance approaches in youth justice - the next passing fad or a sea change for the positive? Youth Justice Journal, December 2017, online first. 
Haydon, D. (2014) Early Intervention for the Prevention of Offending in northern Ireland. Youth Justice, 14/3: 226-240.

Hazel, N. (2008) Cross-National Comparison of Youth Justice. London: YJB.

Home Office (1998) The Crime and Disorder Act. London: Home Office.

Hopkins-Burke, R. (2016) Young People, Crime and Justice. Abingdon: Routledge.

Jamieson, J. (2012) Bleak Times for Children? The Anti-social Behaviour Agenda and the Criminalization of Social Policy. Social Policy and Administration, 46/4: 93109.

Johns, D, Williams, K and Haines, K. (2017) Ecological Youth Justice: Understanding the Social Ecology of Young People's Prolific Offending. Youth Justice Journal, 17 (1): 3-21.

Kelly, L. (2012) Representing and Preventing Youth Crime and Disorder: Intended and Unintended Consequences of Targeted Youth Programmes in England. Youth Justice, 8/1: 21-37.

Kelly, L. and Armitage, V. (2015) Diverse Diversions: Youth Justice Reform, Localized Practices, and a 'New Interventionist Diversion'? Youth Justice, 15/2: 117133.

Lorenz, E.N. (1963) Deterministic Nonperiodic Flow. Journal of the Atmospheric Sciences 20: 130-141.

Lotti, G. (2016) Tough on Young Offenders: Harmful or Helpful? Warwick Economic Research Papers. https://www2.warwick.ac.uk/fac/soc/economics/research/workingpapers/2016/twerp_ 1126_lotti.pdf. (Accessed June 2017).

McAra, L. and McVie, S. (2015) 'The Case for Diversion and Minimum Necessary Intervention '. In: B. Goldson and J. Muncie (eds) Youth Crime and Justice, London: Sage.

McCord, J. (1978) A thirty-year follow-up of treatment effects. American Psychologist, 33/3: 284-289.

McGrayne, S. (2011) The Theory that Would Not Die. New Haven: Yale University Press.

Ministry of Justice (2017) Youth Justice Statistics: 2015 to 2016. London: MoJ.

Ministry of Justice (2016a) Reducing Reoffending by Young People. London: MoJ.

Ministry of Justice (2016b) The Government Response to Charlie Taylor's Review of the Youth Justice System. London: MoJ. 
Morgan, R. (2002) Annual lecture of the National Centre for Public Policy, Swansea: Swansea University.

Morgan, R. (2009) Report to the Welsh Assembly Government on the question of Devolution of Youth Justice Responsibilities. Cardiff: Welsh Government.

Muncie, J. (2014) Youth and Crime. London: Sage.

National Assembly Policy Unit (2000) Extending Entitlement: Supporting Young People in Wales. Cardiff: National Assembly for Wales.

National Police Chiefs' Council (2015) Child-centred Policing. National Strategy for the Policing of Children and Young People. London: NPCC.

Paylor, I. (2011) Youth justice in England and Wales: a risky business. Journal of Offender Rehabilitation. 50/4: 221-233.

Phoenix, J. (2016) Against Youth Justice and Youth Governance, For Youth Penality. British Journal of Criminology, 56/1: 123-140.

Phoenix, J. and Kelly, L. (2013) 'You Have to do it for Yourself': Responsibilization in Youth Justice and Young People's Situated Knowledge of Youth Justice Practice. British Journal of Criminology, 53/3: 419-437.

Posner, P. (2009) The Pracademic: An Agenda for Re-Engaging Practitioners and Academics. Public Budgeting and Finance, 29/1: 12-26.

Prior, D. and Mason, P. (2010) a different kind of evidence. Looking for 'what works' in engaging young offenders. Youth Justice, 10(3): 211-226.

Richards, K. (2014) Blurred Lines: Reconsidering the Concept of 'Diversion' in Youth Justice Systems in Australia. Youth Justice, 14 (2): 122-139.

Sentencing Council (2017) Sentencing Children and Young People Overarching Principles and Offence Specific Guidelines for Sexual Offences and Robbery Definitive Guideline. London: Sentencing Council.

Smith, R. (2017) Diversion in Youth Justice. What can we Learn from Historical and Contemporary Practices? Abingdon: Routledge.

Smith, R. (2016) Youth Justice: Ideas Policy Practice. Abingdon: Routledge.

Solomon, E. and Garside, R. (2008) Ten years of Labour's youth justice reforms: an independent audit. London: Centre for crime and Justice Studies.

Souhami, A. (2007) Transforming Youth Justice. Occupational Identity and Cultural Change. Cullompton: Willan. 
Souhami, A. The Central Institutions of Youth Justice: Government Bureaucracy and the Importance of the Youth Justice Board for England and Wales. Youth Justice, 14: 209-22.

Stephenson, M., Giller, H. and Brown, S. (2011) Effective Practice in Youth Justice. Abingdon: Routledge.

Sutherland, A. (2009) The 'Scaled Approach' in Youth Justice: Fools Rush In... Youth Justice, 9/1: 44-60.

Taylor, C. (2016) Review of the Youth Justice System in England and Wales. London: Ministry of Justice.

Thorpe, D., Smith, D., Green, C. and Paley, J. (1980) Out of Care - The Community Support of Juvenile Offenders. London: George Allen and Unwin.

Tutt, N. and Giller, H. (1987) Manifesto for Management - The Elimination of Custody. Justice of the Peace, 151: 200-202.

Welsh Government and Youth Justice Board (2014) Children and Young People First. Cardiff: Welsh Government/YJB.

Yates, J. (2012) What Prospects Youth Justice? Children in Trouble in the Age of Austerity, Journal of Social Policy and Administration, 46(4): 432:447.

Youth Justice Board (2018) www.yjresourcehub.uk. (Access January 18 ${ }^{\text {th }}$, 2018).

Youth Justice Board (2017) Prevention in Youth Justice. London: YJB.

Youth Justice Board (2015) YOTs: Making the difference for children and young people, victims and communities Final Report. London: YJB.

Youth Justice Board (2014) AssetPlus Rationale. London: YJB.

Youth Justice Board (2013) Assessment and Planning Interventions Framework AssetPlus. Model Document. London: YJB.

Youth Justice Board (2009) Youth justice: The Scaled Approach. A framework for assessment and interventions. Post-consultation version two. London: YJB. 